\title{
INCIDENCE OF ACUTE RENAL FAILURE IN FULL TERM NEONATES WITH BIRTH ASPHYXIA
}

\author{
Jha CB, ${ }^{1 *}$ Tamrakar $A^{1}$
}

\section{Affiliation}

1. Lecturer, Department of Pediatrics, Birat Medical College Teaching Hospital, Tankisinuwari, Biratnagar, Nepal.

\section{ART I CLE INFO}

Article History

Received : 27 Februrary, 2019

Accepted : 20 April, 2019

Published : 30 April, 2019

(C) Authors retain copyright and grant the journal right of first publication with the work simultaneously licensed under Creative Commons Attribution License CC - BY 4.0 that allows others to share the work with an acknowledgment of the work's authorship and initial publication in this journal.

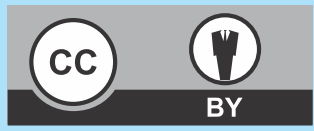

ORA 112

DOI: http://dx.doi.org/10.3126/bjhs.v4i1.23950

\section{* Corresponding Author}

Dr. CB Jha

Lecturer

Department of Pediatrics, Birat Medical College Teaching Hospital, Biratnagar, Nepal.

Email:drcbjha8@gmail.com

ORCID ID: https://orcid.org/0000-0002-0738-9747

\section{Citation}

Jha CB, Tamrakar A. Incidence of Acute Renal Failure in Full Term Neonates with Birth Asphyxia. BJHS 2019;4(1)8: 671-674.

\section{ABSTRACT}

\section{Introduction}

Birth asphyxia is an eventuality having far reaching consequences in the neonatal period. Hypoxia and ischemia can cause damage to almost every tissue and organ in the body and various target organs involved. Renal insult is a recognized complication of birth asphyxia and carries a poor prognosis. Timely detection of renal dysfunction and appropriate management may favorably alter the prognosis in many neonates with birth asphyxia.

\section{Objective}

The present study was done to find out the incidence of acute renal failure in the full term neonates with birth asphyxia.

\section{Methodology}

A cross sectional study was conducted at Birat Medical College Teaching Hospital, Morang,Nepal from $1^{\text {st }}$ September 2017 to $28^{\text {th }}$ February 2018. Fifty full term neonates born with Apgar score of $<6$ at 5 minutes and fulfilling inclusion criteria were enrolled in the study. Asphyxiated neonates having Serum creatinine $>1.5 \mathrm{gm} / \mathrm{dl}$ or urine output $<1 \mathrm{ml} / \mathrm{kg} / \mathrm{hr}$ were labeled as cases of Acute Renal Failure. Blood sample for serum creatinine was collected at $24 \mathrm{hrs}, 48 \mathrm{hrs}$ and $72 \mathrm{hrs}$ of life.

\section{Results}

A total of 50 term asphyxiated neonates were enrolled in the present study. Among them $54 \%$ and $46 \%$ were males and females respectively with male to female ratio of $1.2: 1$. In the present study $62 \%$ of cases developed acute renal failure in either of the first three days of life with mean urine output $1.02 \pm 0.27 \mathrm{ml} / \mathrm{kg} / \mathrm{hr}$ and mean serum creatinine of $1.49 \pm 0.32$ $\mathrm{mg} / \mathrm{dL}$. The incidence of oliguric renal failure was $52 \%$ and non oliguric renal failure was $48 \%$.The association between serum creatinine and urine output was statistically significant.

\section{Conclusion}

In the present study birth asphyxia has been an important cause of neonatal acute renal injury, revealing 31 (62\%) cases. Monitoring urine output and serum creatinine has helped in detecting the asphyxiated neonates with acute renal injury in the early stage.

\section{KEY WORDS}

Acute renal failure, birth asphyxia, neonates 


\section{INTRODUCTION}

Birth asphyxia is an insult to the fetus or newborn due to lack of oxygen (hypoxia) and/or lack of perfusion (ischemia) to various organs. ${ }^{1}$ It is one of the major cause of neonatal death in developing countries like Nepal, India and other South East Asian countries as health services are not much more advance.

The incidence of perinatal asphyxia is about $1-1.57 \%$ in the most centers in developed countries and is usually related to gestational age, birth weight and maternal conditions account for almost $20 \%$ of perinatal mortality. Incidence of birth asphyxia is higher in developing countries and it is mainly due to poor health facilities, illiteracy and ignorance. ${ }^{2}$

Of 130 million newborn infants born each year globally, about 4 million die in the first 4 weeks of life and around $23 \%$ of all newborn deaths are caused by birth asphyxia, with a large proportion of stillbirths. ${ }^{3}$ Following improvement in primary and obstetric care in industrialized countries, the incidence of birth asphyxia has reduced significantly and less than $0.1 \%$ of newborn infants die from birth asphyxia. In developing countries, rate of birth asphyxia are several folds higher, ranging from 4.6 per 1000 in Cape Town to 26 per 1000 in Nigeria. ${ }^{3}$ Incidence of birth asphyxia was 76 per thousand of live births in a study conducted in India. ${ }^{3}$

The assessment of birth asphyxia is made by APGAR score (heart rate, color, respiration, muscle tone and reflex responses ) and the diagnosis is supported by other clinical parameters like multi organ failure, and blood gas analysis.

The target organs of perinatal asphyxia injury are brain, lungs, kidney, liver, bowels etc. In a study on asphyxiated newborns, $34 \%$ had no evidence of organ injury, $23 \%$ had abnormality confined to one organ, $34 \%$ had involvement of 2 organs and $3 \%$ had 3 organs affected. Most frequent abnormalities include involvement of kidney (50\%) followed by central nervous system (25\%), cardiovascular system (25\%) and chest (22\%).

As the acute renal insult following perinatal asphyxia is one of the common complications in neonates, the present study is to carry out the incidence of renal failure in full term neonates with birth asphyxia.

The aim and objectives of this study was to determine the incidence of acute renal failure in term asphyxiated neonates.

\section{METHODOLOGY}

A cross-sectional study was undertaken at Neonatal Intensive Care Unit, Departments of pediatrics, Birat Medical College Teaching Hospital for a period of six months from $1^{\text {st }}$ September 2017 to $20^{\text {th }}$ February 2018. Fifty term neonates 37 to less than 42 weeks of gestational age with 5 minutes APGAR score $<6$ were included in the study where as neonates with gross congenital malformations, prematurity, postmaturity and low birth weight were excluded. The details of baseline information with regards to maternal age, maternal factors, maternal history of per vaginal leaking and its duration, meconium stained amniotic fluid and parity was recorded. First minute, fifth minute and tenth minute APGAR score was recorded in all asphyxiated full term neonates. Birth weight and general physical examination was performed to rule out any congenital anomalies.

In this study, birth asphyxia was defined as fifth minute APGAR score $<6$ and acute renal failure was defined as plasma creatinine more than $1.5 \mathrm{mg} / \mathrm{dL}$ or urine output $<1 \mathrm{ml} / \mathrm{kg} / \mathrm{hr}$

Those newborns with 5 minute APGAR score $<6$ were evaluated and renal function test (sodium, potassium, serum urea and creatinine) were performed on 24 and 48 hours of life. Urine output was monitored till the newborns renal status was normalized. The urine sample in newborns was collected (in female neonates via urinary catheter and in male neonates via urinary bag ) for at least 72 hours or till hospital stay. Along with renal function, serum calcium and other investigation were done when required. The newborns were followed up during hospital stay and details of management were recorded in all the neonates.

The statistical analysis was done by using SPSS.16 software, Chi-square and Fisher exact test was used for statistical significance between the parameters. Sample size: 50 newborns were included for the research purpose.

\section{RESULTS}

A total of 50 term asphyxiated neonates were enrolled in the present study. Among them 54\% and $46 \%$ were males and females respectively with male to female ratio of 1.2:1(Figure 1). At $24 \mathrm{hrs}, 48 \mathrm{hrs}$ and $72 \mathrm{hrs}$ of life $40 \%(20)$, $52 \%(26)$ and $24 \%(12)$ had oliguria respectively. Overall 52 $\%(26)$ of them had oliguric renal failure on either of first three days of life (Table 1).

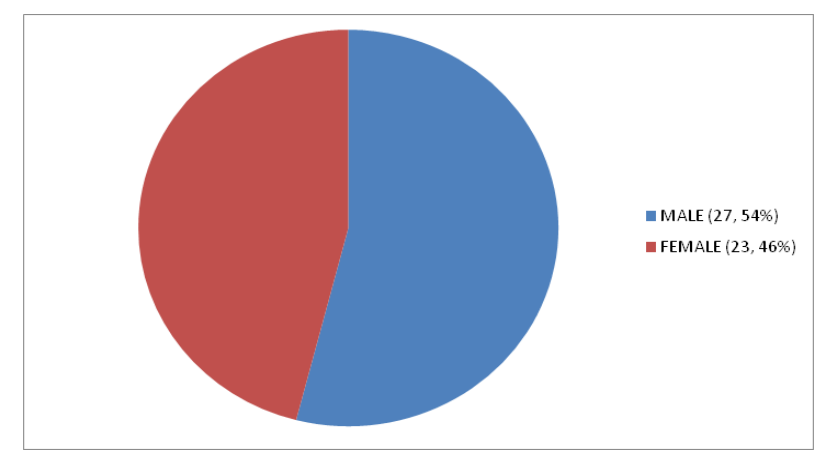

Figure 1: Sex Distribution of Newborns

TABLE 1: Distribution of Newborns According to Urine Output on $1^{\text {st }} 3$ Days of Life

\begin{tabular}{ccc} 
DAY & $\begin{array}{c}\text { Number of newborns (\%) } \\
\text { having urine output } \\
<1 \mathrm{ml} / \mathrm{kg} / \mathrm{hr}\end{array}$ & $\begin{array}{c}\text { Number of newborns (\%) } \\
\text { having urine output } \\
\geq 1 \mathrm{ml} / \mathbf{k g} / \mathrm{hr}\end{array}$ \\
Day 1 & $20(40 \%)$ & $30(60 \%)$ \\
Day 2 & $26(52 \%)$ & $24(48 \%)$ \\
Day 3 & $12(24 \%)$ & $38(76 \%)$ \\
On either of & $26(52 \%)$ & $24(48 \%)$ \\
3 days & & \\
\hline
\end{tabular}


Similarly at $24 \mathrm{hrs}, 48 \mathrm{hrs}$ and $72 \mathrm{hrs}$ of life $32 \%(16), 26 \%$ (13) and $22 \%(11)$ had raised creatinine level respectively (Table 2). Thirty percent (15) of the studied neonates had acute renal failure and oliguria while $12 \%$ (6) of them had non oliguric renal failure (Table 3 ). In the present study $62 \%$ of cases developed acute renal failure in either of the first three days of life with mean urine output $1.02 \pm 0.27 \mathrm{ml} / \mathrm{kg} /$ $\mathrm{hr}$ and mean serum creatinine of $1.49 \pm 0.32 \mathrm{mg} / \mathrm{dl}$. The incidence of oliguric renal failure was $52 \%$ and non oliguric renal failure was $48 \%$.The association between serum creatinine and urine output was statistically significant.

Table 2: Distribution of Newborns According to Serum Creatinine up to 3 Days of Life

\begin{tabular}{lcc} 
DAY & $\begin{array}{c}\text { Number of newborns having } \\
\text { serum creatinine (\%) } \\
>1.5 \mathrm{mg} / \mathrm{dL}\end{array}$ & $\begin{array}{c}\text { Number of newborns having } \\
\text { serum creatinine (\%) } \\
<1.5 \mathrm{mg} / \mathrm{dL}\end{array}$ \\
\hline Day 1 & $16(32 \%)$ & $34(68 \%)$ \\
Day 2 & $13(26 \%)$ & $37(74 \%)$ \\
Day 3 & $11(22 \%)$ & $39(78 \%)$ \\
$\begin{array}{l}\text { On either } \\
\text { of 3 days }\end{array}$ & $21(42 \%)$ & \\
\hline
\end{tabular}

Table 3: Relation Between Serum Creatinine and Urine Ouput $(n=50)$

Number of cases Number of cases with Total with urine output $<1 \mathrm{ml} / \mathrm{kg} / \mathrm{hr}$ $\geq 1 \mathrm{ml} / \mathrm{kg} / \mathrm{hr}$ p value

\section{Serum Creatinine}

$\begin{array}{clll}>1.5 \mathrm{mg} / \mathrm{dl} & 15(30 \%) & 6(12 \%) & 21 \\ \leq 1.5 \mathrm{mg} / \mathrm{dl} & 11(22 \%) & 18(36 \%) & 29 \\ \quad \text { Total } & 26(52 \%) & 24(48 \%) & 50\end{array}$

\section{DISCUSSION}

Birth asphyxia is an insult to the fetus or the newborn due to lack of oxygen (hypoxia) and/or lack of perfusion (ischemia) to various organs of sufficient magnitude and duration to produce functional and/or biochemical changes. As kidneys are very sensitive to oxygen deprivation, renal insufficiency may occur within 24 hours of a hypoxic ischemic episode which if prolonged may even lead to irreversible cortical necrosis. ARF is the commonest complication and carries a poor prognosis and may even result in permanent renal damage in up to $40 \%$ of survivors. ${ }^{9}$

This prospective cross sectional study was carried out in $\mathbf{5 0}$ full term asphyxiated neonates to assess the renal functions, to find out the incidence of acute renal failure. Renal function was evaluated by monitoring urine output serum creatinine, Serum creatinine, urine output were estimated at $24 \mathrm{hrs}, 48 \mathrm{hrs}$ and $72 \mathrm{hrs}$. Those having either raised serum creatinine $(>1.5 \mathrm{mg} / \mathrm{dl}$ ) or oliguria $(<1 \mathrm{ml} / \mathrm{kg} / \mathrm{hr}$ ) on either of the three days were considered as cases with acute renal failure.

In the present study 27(54\%) were males and $23(46 \%)$ were females with the ratio of $1.2: 1$, which is almost in conformity with the studies done by Roy B India() (1.28:1), Dalal EA India 1.1:1, Dongol S et al Nepal 1.26:1. The results in the present study is not in conformity to the study done by Gupta BD et $\mathrm{al}^{13}$ and Mangi et $\mathrm{al}^{14}$ who reported male to female ratio 1.96:1, 2.8:1 respectively. The birth weight of the newborns in this study ranged from $2.6-3.8 \mathrm{~kg}$ with mean $2.8 \pm 0.35 \mathrm{~kg}$ which is similar to the study conducted by Gupta et $\mathrm{al}^{13}$ $(2.8 \pm 0.44 \mathrm{~kg})$, Mangi et al ${ }^{14}(2.5 \mathrm{~kg})$.

In this study the serum creatinine value ranged from 0.9$1.93 \mathrm{mg} / \mathrm{dL}$ with mean $1.41 \pm 0.33$.Serum creatinine value on the $1^{\text {st }}, 2^{\text {nd }}$ and $3^{\text {rd }}$ day of life were $1.3 \pm 0.47,1.6 \pm 0.63,1.31 \pm 0.67$ respectively. Mean creatinine value was raised in the second day of life of studied neonates. According to the study done by Roy $^{15}$ et al serum creatinine on day 1 was $1.14 \pm 0.57$ and on $3^{\text {rd }}$ day of life $1.24 \pm 0.5$ which is nearly similar to the present study. The mean serum creatinine value in the present study is comparable to that done by Jayashree et al ${ }^{6}$ in which the mean serum creatinine value was $1.58 \pm 0.58$, but is not comparable to the study done by Gupta et $\mathrm{al}^{13}$ and Aggarwal et $\mathrm{al}^{16}$ where the values were $1.08 \pm 0.49$ and $1.0 \pm 0.5$ respectively. The number of cases having raised serum creatinine $(>1.5 \mathrm{gm} / \mathrm{dL})$ in the $1^{\text {st }}, 2^{\text {nd }}$ and $3^{\text {rd }}$ day of life were $16(32 \%), 13(26 \%)$ and $11(22 \%)$ respectively.. $21(42 \%)$ cases had serum creatinine values raised on either of 3 days of life. The present study was similar to the study done by Gupta et al $^{13}(30 \%)$ Aggarwal et $\mathrm{al}^{16}(56 \%)$ and Hankins Gary D.V. et al ${ }^{17}(59 \%)$.The present study was dissimilar to the study done by Martin Ancel an et $\mathrm{al}^{18}$ and Perlman JM et $\mathrm{al}^{19}$ who reported the elevated serum creatinine values $15 \%$ and $17 \%$ respectively.

In the present study the range of urine output varied from $0.6-1.5 \mathrm{ml} / \mathrm{kg} / \mathrm{hr}$.The mean urine output on day 1 , day 2 , day 3 was $0.9 \pm 0.23,1.0 \pm 0.38,1.17 \pm 0.38 \mathrm{ml} / \mathrm{kg} / \mathrm{hr}$. Urine ouput improved daywise which could be attributed to prompt recognition of it and early administration of fluid boluses and furosemide. Urine output improved on $3^{\text {rd }}$ day of life.This is similar to the observations of Perlman et al who reported transient oliguria on $1^{\text {st }}$ day in $23 \%$ of newborns and urine ouput increased to normal values on $3^{\text {rd }}$ day of life. In this study the mean urine output of three days was $1.02 \pm 0.27 \mathrm{ml} / \mathrm{kg} / \mathrm{hr}$. The mean urine output was comparable to the study done by gupta et al(), which was $1.28 \pm 0.36 \mathrm{ml} / \mathrm{kg} / \mathrm{hr}$.

The incidence of oliguric renal failure was $40 \%(20)$, $52 \%(26), 24 \%(12)$ on $1^{\text {st }}, 2^{\text {nd }}$ and $3^{\text {rd }}$ day of life respectively in the present study. The incidence of oliguria was more on $2^{\text {nd }}$ day of life and again decreased the next day owing to the early intervention and fluid management. This study was comparable to the study done by shah GS et al ${ }^{20}$ in which the incidence of oliguric renal failure were $58.3 \%, 30 \%, 23.3 \%$. on $1^{\text {st }}$ three days of life respectively. The incidence of oliguric renal failure on either of the three days in this study is $52 \%$ which is comparable to the study done by Aggarwal et al(17) $(42 \%)$ and Mohan PV ${ }^{12}$ et al (44\%) but is dissimilar to the study done by Gharehbaghi et $\mathrm{al}^{22}(10 \%)$ and Mangi et al ${ }^{14}$. The incidence of non oliguric renal failure was $48 \%$ where serum creatinine was raised $(>1.5 \mathrm{mg} / \mathrm{dL})$ despite normal urine output( $>1 \mathrm{ml} / \mathrm{kg} / \mathrm{hr}$ ).

Oliguria in this study could be attributed to birth asphyxia which leads vasoconstriction of the afferent arterioles and decreases the blood flow to the kidneys so that glomerular filtration rate decreases leading to oliguria and even anuria. Non oliguric renal failure is a recognized entity secondary to birth asphyxia. Renal parenchymal injury in non oliguric as 
well as oliguric renal failure is essentially similar but heterogenous response of individual nephron and variable damage to tubular epithelium results in anatomical damage of different severity. If damage to tubular epithelium is less severe there occurs decrease in fractional reabsorption which exceeds the decrease in single nephron GFR leading to polyuria in non oliguric renal failure. ${ }^{18}$

The incidence of ARF in the present study is $31(62 \%)$. The incidence of oliguric and non oliguric renal failure were $52 \%$ and $48 \%$ respectively. The incidence of $\operatorname{ARF}(62 \%)$ in the present study is similar to the study results documented by Karlowicz et $\mathrm{al}^{22}(61 \%)$, Aggarwal et $\mathrm{al}^{17}(56 \%)$ and Mangi et $\mathrm{al}^{14}(46 \%)$, but is not in similarity to the study by Gharhebaghi et al $^{21}(36.5 \%)$, Gupta et al (47.14\%). ${ }^{13}$

The variability in the results could be due to difference in place of study, different populations studied and different methods used for assessment of renal functions.

The incidence of oliguric renal failure in this study is $52 \%$ which is comparable to the study done Aggarwal et $\mathrm{al}^{16}$ (42\%) and Mohan PV et $\mathrm{al}^{12}(44 \%)$ but is dissimilar to the study done by Gharehbaghi et al $^{21}$

The lesser incidence in Gharehbaghi study could be due to the fact that they excluded sepsis, respiratory distress syndrome and heart failure while evaluating renal failure which were not excluded in the present study. The incidence of non oliguric renal failure in this study is $48 \%$ which is comparable to Aggarwal et $\mathrm{al}^{16}(58 \%)$ and Mohan PV et $\mathrm{al}^{12}$ (56\%). but was not comparable to the study done by Gharehbaghi et $\mathrm{al}^{21}(90 \%)$ and which was in much higher sides.

\section{CONCLUSION}

Out of the 50 term asphyxiated newborns in our study, $31(62 \%)$ of the cases developed acute renal failure in the first three days of life considering serum creatinine $>1.5$ $\mathrm{mg} / \mathrm{dL}$ or oliguria $(<1 \mathrm{ml} / \mathrm{kg} / \mathrm{hr})$.

\section{LIMITATION OF THE STUDY}

The limitation of the study was the sample size which was small and the cases were included from only one center.

\section{ACKNOWLEDGEMENTS}

We are thankful to all the children and their parents who agreed to be the part of this assessment.

\section{CONFLICT OF INTEREST}

None

\section{FINANCIALDISCLOSURE}

None

\section{REFERENCES}

1. Cloherty JP, Eichewald EC, Hansen AR, Stark AR. Manual of neonatal care. 6th ed. Philadelphia. Lipponcot Williams and Wilkins. 2012.55: Perinatal Asphyxia and Hypoxic Ischemic Encephalopathy; 711-28.

2. Park K. Park's text book of preventive and social medicine. 17th ed. Jabalapur. M/s Banarasidas Bhanot Publishers; 2002.5: Respiratory infections; 151-9.

3. Kumari S, Sharma M, Yadav M, Saraf A, Kabra M, Mehra R. Trends in neonatal outcome with low Apgar score. Indian J pediatr 1993;60(3):415-22. (PMID: 8253491)

4. Haider BA, Bhutta ZA. Birth asphyxia in developing countries" current status and public health implications. Curr Probl Pediatr Adolesc Health Care 2006;36(5)178-88. (PMID: 16631096)

5. Olavarria F, Krause S, Barranco L, Herrmann F, Paez V, Mezzano S et al. Renal fuction in full term newborns following neonatal asphyxia. Clin Pediatr 1987;26(7):334-8. (PMID: 3595038)

6. Jayashree G, Dutta AK, Sarna MS, Saili A. Acute renal failure in asphyxiated newborns. Indian Pediatr. 1991;28(1) :19-23. (PMID: 2055607)

7. Airede $A$, Bello $M$, Weerasinghe $H D$. Acute renal failure in the newborn: incidence and outcome. J Pediatr Child Health. 1997;33(3): 246-9 (PMID: 9259302)

8. Pejovic B, Peco-Antic A, Dunjic R. Acute oliguric renal failure in hypoxic neonates born at full term. Srp Arh Celok Lek. 2002;130(1112):367-70.(PMID: 12751158)

9. Brocklebank JT. Renal failure in the newly born. Arch Dis Child. 1988;63(8):991-4. (PMID: 3046517)

10. Ekta A Dalal, Nayan L Bodar. A study on birth asphyxia at tertiary health Centre. Natl J Med Res. 2013;3(4):374-6.(Scopemed)

11. Dongol S, Singh J, Shrestha S, Shakya A. Clinical Profile of Birth Asphyxia in Dhulikhel Hospital: A Retrospective study. J Nepal Pediatr Society. 2010;30(3):141-5. (DOI: 10.3126/jnps.v30i3.3916)

12. Mohan PV, Pai PM. Renal insult in asphyxia neonatorum. Indian Pediatr. 2000;37(12):1102-6. (PMID: 11042710)
13. Gupta BD, Sharma P, Bagla J, Parakh M, Soni JP. Renal failure in asphyxiated neonates. Indian pediatr. 2005;42(9):928-34. (PMID: 16208054)

14. Mangi ZA, Junejo B, Shaikh S, Jamro S. . Birth Asphyxia relationship between hypoxic ischemic encephalopathy grading and development of acute renal failure in indoor term neonates at Chandika Medical college children Hospital Larkana. Medical Channel:2006;15(4):148-52.

15. Roy B, Mondal G. Study of Renal Profile in babies with Perinatal asphyxia in a Tertiary Care Hospital: A prospective case control study. J Nepal Pediatr Society. 2013;33(3):206-12. (DOI:10.3126/ JNPS. V.33i3.8385)

16. Aggarwal A, Kumar P, Chowdhary G, Majumdar S, Narang A. Evaluation of renal functions in asphyxiated newborns. J Trop Pediatr. 2005;51(5):295-9. (PMID: 16000344)

17. Hankins GD et al. Neonatal organ system injury in acute birth asphxyia sufficient to result in neonatal encephalopahty. Obstet Gynaecol 2002;99(1):688-91. (PMID: 11978273)

18. Martin Ancel A, Gaya Fransciso, Cabanas Fernando, Buergeros Margarita. Multiple organ involvement in perinatal asphyxia. J Pediatr. 1995;127(5):786-93. (PMID: 7472837)

19. Perlman JM, Tack ED, Martin T, Shackelford G, Amon E. Acute systemic organ injury in term infants after asphyxia. Am J Dis Child. 1989;143(5):617-20. (PMID: 2718998)

20. Shah GS, Agrawal J, Mishra OP, Chalise S. Clinico-biochemical profile of neonates with Birth Asphyxia in Eastern Nepal. J Nepal Pediatr Society. 2012;32(3):206. (DOI: 10.3126/jnps.v32i3.7626)

21. Gharehbaghi MM, Peirovifar A MD. Evaluating causes of acute renal failure in newborn infants. Pak J Med Sci. 2007;23(6):877-80.

22. Karlowicz MG, Adelman RD. Non oliguric and oliguric acute renal failure in asphyxiated term neonates. Pediatr Nephrol. 1995;9(6):718-22. (PMID: 8747112) 